\title{
IMPACT OF POTASSIUM FOLIAR APPLICATION AT VARIOUS GROWTH STAGES ON RICE PRODUCTIVITY AND GRAIN QUALITY CHARACTERISTICS AT DIFFERENT STORAGE PERIODS
}

\author{
A.S. Gharieb \\ Rice Research and Training Center, Field Crops Research Institute, Agricultural \\ Research Center, Kafr El-Sheikh, Egypt.
}

Received: Apr. 12, 2021

Accepted: Apr. 28, 2021

\begin{abstract}
The present study was carried out at the Experimental Farm of Agricultural Research Station, Sakha, Kafr El-Sheikh, Egypt over 2018 and 2019 rice growing seasons. This investigation aimed to study the effect of potassium sulphate foliar application on the productivity and grain quality characteristics of rice (Sakha 109 variety). The potassium sulphate was applied at the concentration of $1 \% \mathrm{~K}_{2} \mathrm{SO}_{4}$ at various growth stages. The examined treatments were; $\mathrm{K}_{1}$ : Control (distilled water spray), $\mathrm{K}_{2}$ : spray at 20 day after transplanting (DAT), $K_{3}$ : spray at 35 DAT, $K_{4}$ : spray at 50 DAT, $K_{5}$ : spray at 20 and 35 DAT, $K_{6}$ : spray at 20 and 50 DAT, $K_{7}$ : spray at 35 and 50 DAT, $K_{8}$ : spray at 20, 35 and 50 DAT. The experiment was planned in a Randomized Complete Block Design with four replications. At harvest, the studied characteristics were plant height, number of panicles per hill, panicle length, panicle weight, number of filled grains per panicle, unfilled grains percentage,1000-grain weight and total yield of both grain and straw per hectare. The grain quality characteristics (Hulling, milling, head rice, nitrogen content and potassium content) were measured at different storage periods (0, 3, 6 and 9 months after harvest). The results showed that all studied traits were significantly affected by potassium treatments. Potassium application improved the grain quality characteristics at different storage periods. Foliar application of potassium three times at different growth stages $\left(\mathrm{K}_{8}\right)$ surpassed other treatments in terms of yield quantity and quality.
\end{abstract}

Key words: Potassium fertilizer, Yield rice quality, Milling, Head rice.

\section{INTRODUCTION}

Rice is the essential food commodity and carbohydrate source for a large portion of the Egyptian population. The total local white rice consumption is estimated to be about 4.0 million metric tons in 2015 (FAO, 2016). This production is seasonal while consumption is continuous throughout the year. Proper storage conditions must be provided for the paddy after harvest until it is needed for consumption. During storage for rough rice, it has been reported that storage arranges of changes in the physicochemical, pasting, and nutritional properties of rice occur, which affects the rice quality (Zhou et al., 2002; Ahmad et al., 2017 and El-Dalil, 2017). To minimize these changes, low temperature and controlled atmosphere storage are usually concluded as the recommended methods. However, low-temperature storage is considered expensive due to the high initial cost of cooling systems and high energy consumption during its operation, while controlled atmosphere storage needs special packaging and storing facilities, which are costly as well. Furthermore, the expenses of facility maintenance are also high, thus the suggested methods cannot be suitably applied in developing countries (Nguyen and Goto, 2009 and Park et al., 2012). 
It is very important to find new innovative solutions and friendly to the environment to increase the storage ability without affecting the chemical properties of rice grain quality. The proper and balanced application of fertilizers is one of the most important factors for increasing the yield and quality of the crops (Kundu et al., 2020). In rice cultivation, the farmers are bestowing much attention only to $\mathrm{N}$ fertilization and very often $\mathrm{K}$ application is carried out at a minimal level, mostly ignoring $\mathrm{K}$ fertilization. This practice of imbalance and inadequate fertilizer application affects soil productivity in general and particularly depletes the essential nutrients. Besides, some investigation supported that potassium (K) was among essential elements that could increase the maintain its chemical properties without decreasing the quality (Jagathjothi et al., 2012; Khan et al., 2012; Kundu et al., 2020 and Mirtaleb et al., 2021). Potassium (K) plays essential roles in stomata activity, energy transfer, phloem transport, cation-anion balance and stress resistance (Wang et al., 2013). It also helps in photosynthesis, carbohydrate distribution and starch synthesis in storage organs which in turn helps in higher grain yield (White et al., 2010).

Potassium requirement is as much as nitrogen for cereals. Being cationic primary nutrient, potassium triggers and wields a variety of physiological processes viz. photosynthesis, protein synthesis, activation of enzymes, and water status maintenance in plant tissues (Marschner, 2011). It also influences synthesis, translocation, transformation, storage and compartmentation of carbohydrates, quality of the product, and post-harvest characteristics as well as plants resistance to stresses and diseases (Mardanluo et al., 2018).
In field conditions, potassium is absorbed faster than other elements such as phosphorous and nitrogen by crops. On the other hand, potassium plays a significant role in increasing the efficiency of nitrogen utilization in crops (Jian-chang, 2004). Unlike phosphorus and nitrogen, $K$ ions are not easily converted to organic compounds, however, it plays an important role in the translocation of important metabolites such as photosynthetic products, which in turn can increase plant yield (Boonchuay et al., 2013). Li-Jun et al., (2011) reported that $K$ has a significant effect on the quality of rice grains. In the life cycle of rice crop, a large quantity of potassium is needed, and it has also been shown that continuous supply of potassium during the heading stage has a significant effect on crop yield and quality (Fageria et al., 2003 and Jianchang, 2004). Srivastava et al., (2009) indicated that increased potassium fertilizer resulted in lower softness, stronger aroma, glassier and whiter appearance in basmati rice. In addition, the increase in grain yield and quality in japonica rice has been reported by Wang et al., (2004). Mirtaleb et al., (2021) reported that the foliar spray of $K$ significantly improved the mineral nutrients and quality of brown and milled of rice.

The aim of the study is the effect of potassium foliar spray in different growth stages and the extent of the influence on the rice grain quality characteristics of the rice crop grains at different storage periods.

\section{MATERIALS AND METHODS}

A dual-season field experiment was conducted at the Experimental Farm of Sakha Agriculture Research Station, Kafr El-Sheikh, Egypt, during 2018 and 2019 rice growing seasons, to study the impact of potassium sulphate foliar 
application at various growth stages on yield, yield component and grain quality characters at different storage periods of Sakha109 rice variety. The experimental site is located $31^{\circ} 5^{\prime} 17^{\prime \prime}$ North latitude and $30^{\circ} 56^{\prime} 44^{\prime \prime}$ East longitude at an altitude of $8 \mathrm{~m}$ from mean sea level. The preceding crop was wheat in the two seasons. Before land preparation, initial representative soil samples were collected at $0-15 \mathrm{~cm}$ depth from different spots and adjusted for physical and chemical analysis. The physical and chemical characteristics of the experimental soil (Jones, 2001) are specified in Table 1.

The studied treatments consisted of foliar spray of $1 \% \quad \mathrm{~K}_{2} \mathrm{SO}_{4}$ at different growth stages of rice plant as follows:

$\mathrm{K}_{1}$ : Control (distilled water spray)

$\mathrm{K}_{2}$ : Foliar spray of $1 \% \mathrm{~K}_{2} \mathrm{SO}_{4}$ at 20 days after transplanting (DAT)

$\mathrm{K}_{3}$ : Foliar spray of $1 \% \mathrm{~K}_{2} \mathrm{SO}_{4}$ at $35 \mathrm{DAT}$
$\mathrm{K}_{4}$ : Foliar spray of $1 \% \mathrm{~K}_{2} \mathrm{SO}_{4}$ at 50 DAT

$\mathrm{K}_{5}$ : Foliar spray of $1 \% \mathrm{~K}_{2} \mathrm{SO}_{4}$ at 20 and 35 DAT

$\mathrm{K}_{6}$ : Foliar spray of $1 \% \mathrm{~K}_{2} \mathrm{SO}_{4}$ at 20 and 50 DAT

$\mathrm{K}_{7}$ : Foliar spray of $1 \% \mathrm{~K}_{2} \mathrm{SO}_{4}$ at 35 and 50 DAT

$\mathrm{K}_{8}$ : Foliar spray of $1 \% \mathrm{~K}_{2} \mathrm{SO}_{4}$ at 20,35 and 50 DAT

The experiment was planned in a Randomized Complete Block Design. The seedbed was prepared and well ploughed; dry leveled, submerged by irrigation water followed by wet leveling. Calcium mono phosphate $\left(15.5 \% \mathrm{P}_{2} \mathrm{O}_{5}\right)$ at the rate of $36 \mathrm{~kg} \mathrm{P}_{2} \mathrm{O}_{5}$ ha $^{-1}$ was added during dry land preparation. Nitrogen in the form of urea (46.5\%) was added into the dry soil then incorporated just before flooding at the rate of $80 \mathrm{~kg} \mathrm{~N} \mathrm{ha}^{-1}$. Zinc was applied after seedbed wet leveling as $\mathrm{ZnSO}_{4}$ at the rate of $57 \mathrm{~kg} \mathrm{ha}^{-1}$.

Table 1: Some chemical analyses of the experimental soil before planting in 2018 and 2019 seasons.

\begin{tabular}{|l|c|c|}
\hline \multirow{2}{*}{ Soil chemical properties } & \multicolumn{2}{|c|}{ Seasons } \\
\cline { 2 - 3 } & 2018 & 2019 \\
\hline Soil texture & Clayey & Clayey \\
Clay \% & 55.90 & 56.00 \\
Silt \% & 31.50 & 32.00 \\
Sand \% & 12.60 & 12.00 \\
\hline $\mathrm{pH}(1: 2.5$ soil suspension) & 8.05 & 8.20 \\
Ec (ds.m ${ }^{-1}$ ) & 2.00 & 2.05 \\
Available ammonium (ppm) & 13.50 & 12.60 \\
Available Nitrate (ppm) & 10.30 & 11.80 \\
Available P (ppm) & 14.00 & 12.00 \\
Available K (ppm) & 350.10 & 366.50 \\
\hline Anions (meq. $\left.\mathrm{L}^{-1}\right)$ & & \\
$\mathrm{CO}_{3}^{--}$ & 0.00 & 0.00 \\
$\mathrm{HCO}_{3}^{--}$ & 5.60 & 5.00 \\
$\mathrm{Cl}^{-}$ & 14.00 & 14.00 \\
$\mathrm{SO}_{4}^{--}$ & 2.70 & 2.00 \\
\hline $\mathrm{Cations}^{--}$meq. $\left.\mathrm{L}^{-1}\right)$ & & \\
$\mathrm{Ca}^{++}$ & 7.20 & 6.00 \\
$\mathrm{Mg}^{++}$ & 2.60 & 1.50 \\
$\mathrm{Na}^{++}$ & 12.00 & 13.00 \\
$\mathrm{~K}^{+}$ & 0.50 & 0.50 \\
\hline
\end{tabular}


The permanent field was opened by a tractor, and then the land was ploughed and cross-ploughed two times to obtain optimum tillage and puddle condition. The permanent field was fertilized by calcium mono phosphate $\left(15.5 \% \mathrm{P}_{2} \mathrm{O}_{5}\right)$ at the rate of $36.9 \mathrm{~kg} \mathrm{P}_{2} \mathrm{O}_{5}$ ha $^{-1}$ during land preparation. Nitrogen fertilizer at the rate of $165.6 \mathrm{~kg} \mathrm{~N} \mathrm{ha}^{-1}$ in the form of urea $(46.5 \% \mathrm{~N})$ was added into splits first one was $(2 / 3)$ of recommended rate as basal application and second one $(1 / 3)$ was applied at 30 DAT. After the application of fertilizers, the experimental plots were irrigated and slightly leveled. Thirty-day old seedlings were uprooted from the nursery and well distributed through the plots. Seedlings were manually transplanted on $15^{\text {th }}$ and $17^{\text {th }}$ of June, 2018 and 2019 respectively, into $12 \mathrm{~m}^{2}$ plots in $20 \times 20 \mathrm{~cm}$ spacing as a distance between hills and rows. Herbicides application was used as recommended (4.8 litter ha-1 Saturn 50\%), well mixed with enough sand to make it easily for homogenous distribution and broadcast in the 2-3 cm depth water of the field.

Ten $\mathrm{kg}$ of rough rice was taken randomly from different replication of all treatments and adjusted at $14 \%$ moisture content. Rice samples were packed on jute bags and stored under room temperature for different storage periods $(0,3,6$, and 9 months). The grain quality characteristics (hulling, milling and head rice percentages) were measured at the above mentioned at a storage periods according to the methods reported by Adair (1952).

\section{The studied characters}

At harvest, plant height $(\mathrm{cm})$ and the number of panicles per hill were measured. Ten panicles were collected randomly to estimate the panicle length (cm), panicle weight (g), number of filled grains per panicle, unfilled grains $\%$ and 1000 -grain weight $(\mathrm{g})$. The total yield of both grain and straw was recorded as tons per hectare. The nitrogen content of milled grains was measured using the Microkieldahl method (Jackson, 1967) to determine nitrogen uptake. The Potassium content of grain was determined to calculate potassium uptake using Elico CL378 Flame Photometer (RHYS international LTD, India) according to methods reported by Peterburgski (1968).

The collected data were subjected to statistical analysis according to the procedure described by Gomez and Gomez (1984). Treatments means were compared by Duncan's multiple range test (Duncan, 1955). A combined analysis was used among storage periods in each season. All statistical analyses were performed using variance technique by means of "MSTAT" computer software package.

\section{RESULTS AND DISCUSSION}

Data in Table 2 show that plant height, numbers of panicles per hill and panicle length at harvest were significantly affected by foliar application of potassium at different growth stages in the 2018 and 2019 seasons. Potassium foliar application significantly increased the values of plant height, numbers of panicles per hill and panicle length compared with the control treatment. Plants treated with potassium foliar spray three times $\left(K_{8}\right)$ recorded the highest values of plant height, numbers of panicles per hill and panicle length in the both seasons. The superiority of growth attributes of rice due to potassium foliar application at different growth stages could be ascribed to the overall improvement in plant growth, vigor and production of photosynthesis owing to increased availability, absorption and translocation of nutrients in plant. These results are confirmed with the findings of (Islam et al., 2017). Ali et al., (2005) reported that foliar application of $\mathrm{K}_{2} \mathrm{SO}_{4}$ gave better number of tillers and panicle length. 
Table 2: Plant height, number of panicles per hill and panicle length at harvest as affected by different potassium treatments in the 2018 and 2019 seasons.

\begin{tabular}{|c|c|c|c|c|c|c|}
\hline \multirow[t]{2}{*}{$\begin{array}{c}\text { Spray of } 1 \% \\
\mathrm{~K}_{2} \mathrm{SO}_{4} \text { at DAT }\end{array}$} & \multicolumn{2}{|c|}{ Plant height (cm) } & \multicolumn{2}{|c|}{ No. of panicle/hill } & \multicolumn{2}{|c|}{$\begin{array}{l}\text { Panicle length } \\
\text { (cm) }\end{array}$} \\
\hline & 2018 & 2019 & 2018 & 2019 & 2018 & 2019 \\
\hline$\left(K_{1}\right)$ Control & $94.50 \mathrm{~d}$ & $96.50 \mathrm{c}$ & $16.50 \mathrm{~d}$ & $16.70 \mathrm{~d}$ & $20.50 \mathrm{~b}$ & $20.70 \mathrm{~b}$ \\
\hline$\left(K_{2}\right) 20$ & $100.8 \mathrm{abc}$ & $98.80 \mathrm{bc}$ & $19.20 \mathrm{ab}$ & $18.90 \mathrm{ab}$ & $21.10 \mathrm{~b}$ & $22.40 \mathrm{a}$ \\
\hline$\left(K_{3}\right) 35$ & $97.80 \mathrm{bcd}$ & $98.20 \mathrm{c}$ & $18.10 \mathrm{bc}$ & $18.20 \mathrm{bc}$ & $22.70 \mathrm{a}$ & $22.60 \mathrm{a}$ \\
\hline$\left(K_{4}\right) 50$ & $96.80 \mathrm{~cd}$ & $97.40 \mathrm{c}$ & $16.90 \mathrm{~cd}$ & $16.90 \mathrm{~cd}$ & $23.10 \mathrm{a}$ & $22.90 \mathrm{a}$ \\
\hline$\left(K_{5}\right) 20+35$ & $102.2 \mathrm{ab}$ & $99.80 \mathrm{abc}$ & $19.70 \mathrm{ab}$ & $19.20 \mathrm{ab}$ & $22.90 \mathrm{a}$ & $22.70 \mathrm{a}$ \\
\hline$\left(\mathrm{K}_{6}\right) 20+50$ & $101.8 \mathrm{ab}$ & $101.8 \mathrm{ab}$ & $19.10 \mathrm{ab}$ & $18.90 \mathrm{ab}$ & $23.30 \mathrm{a}$ & $23.00 \mathrm{a}$ \\
\hline$\left(K_{7}\right) 35+50$ & $99.90 \mathrm{abc}$ & $97.60 \mathrm{c}$ & $18.40 \mathrm{bc}$ & 18.30abc & $23.60 \mathrm{a}$ & $23.50 \mathrm{a}$ \\
\hline$\left(\mathrm{K}_{8}\right) 20+35+50$ & $103.1 \mathrm{a}$ & $102.5 \mathrm{a}$ & $20.10 \mathrm{a}$ & $19.80 \mathrm{a}$ & $23.70 \mathrm{a}$ & $23.60 \mathrm{a}$ \\
\hline F Test & * & * & * & * & ** & ** \\
\hline
\end{tabular}

*, ** and N.S. indicate $P<0.05, P<0.01$ and not significant, respectively. Means of each factor designated by the same latter are not significantly different at $5 \%$ level using Duncan's Multiple Range Test

Data in Table 3 revealed that panicle weight, numbers of filled grain per panicle, number of unfilled grain per panicles and 1000-garain weight were significantly affected by potassium foliar application in both seasons. Foliar application of potassium increased the panicle weight, number of filled grain per panicle and 1000-grain weight in the two seasons. The highest values for these characteristics were found when the rice plants sprayed by potassium three time $\left(K_{8}\right)$ followed by plants were sprayed by potassium two times at any stages $\left(K_{5}, K_{6}\right.$ and $K_{7}$ ) with no significant different among them in two seasons. On the other hand, data indicated that foliar application of potassium significantly decreased the number of unfilled grain. The highest values of the number of unfilled grain per panicle were obtained when the plants were untreated with potassium (control). This may be due to the continuous supply of potassium to the crop during the growth seasons caused an increase in fertilizer use efficiency consequently potassium uptake. These results were also supported by Naeem (2016); Kundu et al., (2020); Rekani (2020) and Mirtaleb et al., (2021).

Grain and straw yields/ha as well as harvest index as affected by potassium treatments in the 2018 and 2019 growing seasons are presented in Table 4. Paddy yield was significantly increased by all tested potassium fertilizer treatments compared with the control. The highest value of grain yield/ha was obtained when the plants were treated with potassium foliar spray three times $\left(K_{8}\right)$ followed by plants that have been sprayed with potassium twice or once at 50 DAT without any significant 


\section{A.S. Gharieb}

differences among them in the two seasons. Data indicated also that there are significant increases in straw yield/ha as foliar application of potassium was applied in the both seasons. The greatest value of straw yield was found with plants treated with potassium three times $\left(K_{8}\right)$ followed by plants that have been sprayed with potassium twice $\left(K_{5}, K_{6}\right.$ and $K_{7}$ ) without any significant differences among them. Furthermore, there were no significant differences in harvest index among the tested treatments in the two seasons. The increase in grain yield/ha with potassium fertilizer application was mainly due to the improvement of yield components. It is well known fact that $\mathrm{K}$ serves a vital role in photosynthesis by directly increasing growth and leaf area index and hence $\mathrm{CO}_{2}$ assimilation enhance outward translocation of more
ATP essential for vigorous growth of plants. Many researchers have reported the positive response of $\mathrm{K}_{2} \mathrm{SO}_{4}$ foliar application to rice (Islam et al., 2017; Okasha et al., 2019; Kundu et al., 2020; Rekani, 2020 and Mirtaleb et al., 2021). Naeem (2016) suggested that foliar application of potassium sulfate at 15 DAT and at panicle initiation was active, appropriate and could produce rice yield equal to the yield obtained with soil application of potassium sulfate at the rate of $119 \mathrm{~kg} \mathrm{ha}^{-1}$. He also reported that from the economic point of view side, spraying with potassium sulfate at the concentration of $2 \%, 15$ DAT plus spray with the same concentration at panicle initiation (PI) was the best treatment to grain more yield with high economic value.

Table 3: Panicle weight, number of filled grain per panicles, number of unfilled grain per panicles and 1000-garain weight as affected by different potassium treatments in the 2018 and 2019 seasons.

\begin{tabular}{|c|c|c|c|c|c|c|c|c|}
\hline \multirow[t]{2}{*}{$\begin{array}{l}\text { Spray of } 1 \% \\
\mathrm{~K}_{2} \mathrm{SO}_{4} \text { at DAT }\end{array}$} & \multicolumn{2}{|c|}{$\begin{array}{l}\text { Panicle weight } \\
\text { (g) }\end{array}$} & \multicolumn{2}{|c|}{$\begin{array}{l}\text { Number of filled } \\
\text { grain/panicle }\end{array}$} & \multicolumn{2}{|c|}{$\begin{array}{c}\text { Number of } \\
\text { unfilled } \\
\text { grain/panicle }\end{array}$} & \multicolumn{2}{|c|}{$\begin{array}{c}\text { 1000- grain weight } \\
\text { (g) }\end{array}$} \\
\hline & 2018 & 2019 & 2018 & 2019 & 2018 & 2019 & 2018 & 2019 \\
\hline$\left(\mathrm{K}_{1}\right)$ Control & $2.63 d$ & $2.66 \mathrm{c}$ & $88.9 c$ & 91.1c & $13.1 a$ & $10.2 a$ & $25.37 e$ & $25.82 d$ \\
\hline$\left(K_{2}\right) 20$ & $2.94 \mathrm{~cd}$ & $2.79 \mathrm{c}$ & $101.7 \mathrm{bc}$ & 99.4bc & 10.1b & $6.5 b$ & 25.92de & $26.12 \mathrm{~cd}$ \\
\hline$\left(K_{3}\right) 35$ & $2.99 \mathrm{~cd}$ & $2.83 b c$ & 112.3ab & 108.3ab & $9.1 b c$ & $5.5 b$ & 26.07cde & 26.88abc \\
\hline$\left(K_{4}\right) 50$ & 3.11bc & 2.94abc & 109.2ab & $101.3 b c$ & $7.5 \mathrm{bcd}$ & 4.4b & $26.72 \mathrm{bcd}$ & $26.57 \mathrm{bcd}$ \\
\hline$\left(K_{5}\right) 20+35$ & 3.34abc & 3.01abc & 114.3ab & $110.1 \mathrm{ab}$ & 7.7bcd & $4.8 b$ & 26.23b-e & 26.88abc \\
\hline$\left(K_{6}\right) 20+50$ & 3.49ab & $3.18 a b$ & 111.9ab & $104.3 a b$ & $6.9 \mathrm{~cd}$ & $4.2 b$ & 26.85abc & 26.73abc \\
\hline$\left(K_{7}\right) 35+50$ & $3.54 a b$ & $3.21 a$ & 112.9ab & 109.7ab & $5.8 d$ & $4.2 b$ & 27.02ab & 27.03ab \\
\hline$\left(K_{8}\right) 20+35+50$ & $3.61 a$ & $3.30 a$ & $119.5 a$ & $113.9 a$ & $5.2 d$ & $3.8 b$ & $27.63 a$ & $27.48 a$ \\
\hline F Test & ** & ** & ** & ** & ** & ** & * & * \\
\hline
\end{tabular}

*, ** and N.S. indicate $P<0.05, P<0.01$ and not significant, respectively. Means of each factor designated by the same latter are not significantly different at $5 \%$ level using Duncan's Multiple Range Test 
Table 4: Grain yield, straw yield and Harvest Index as affected by different potassium treatments in the 2018 and 2019 seasons.

\begin{tabular}{|l|c|c|c|c|c|c|}
\hline \multicolumn{1}{|c|}{$\begin{array}{c}\text { Spray of 1\% } \\
\mathrm{K}_{2} \mathrm{SO}_{4} \text { at DAT }\end{array}$} & \multicolumn{2}{|c|}{$\begin{array}{c}\text { Grain } \\
\text { Yield } \\
\left(\mathrm{t} \mathrm{ha}^{-1}\right)\end{array}$} & \multicolumn{2}{c|}{$\begin{array}{c}\text { Straw } \\
\text { Yield } \\
\left(\mathrm{t} \mathrm{ha}^{-1}\right)\end{array}$} & \multicolumn{2}{c|}{$\begin{array}{c}\text { Harvest } \\
\text { index }\end{array}$} \\
\cline { 2 - 8 } & 2018 & 2019 & 2018 & 2019 & 2018 & 2019 \\
\hline$\left(\mathrm{K}_{1}\right)$ Control & $9.798 \mathrm{~d}$ & $9.514 \mathrm{c}$ & $11.90 \mathrm{c}$ & $11.56 \mathrm{c}$ & $0.452 \mathrm{a}$ & $0.451 \mathrm{a}$ \\
\hline$\left(\mathrm{K}_{2}\right) 20$ & $10.01 \mathrm{~cd}$ & $9.882 \mathrm{bc}$ & $12.10 \mathrm{bc}$ & $11.81 \mathrm{bc}$ & $0.453 \mathrm{a}$ & $0.456 \mathrm{a}$ \\
\hline$\left(\mathrm{K}_{3}\right) 35$ & $10.27 \mathrm{bc}$ & $10.13 \mathrm{ab}$ & $12.00 \mathrm{c}$ & $11.57 \mathrm{c}$ & $0.461 \mathrm{a}$ & $0.467 \mathrm{a}$ \\
\hline$\left(\mathrm{K}_{4}\right) 50$ & $10.35 \mathrm{abc}$ & $10.27 \mathrm{ab}$ & $11.94 \mathrm{c}$ & $11.48 \mathrm{c}$ & $0.464 \mathrm{a}$ & $0.472 \mathrm{a}$ \\
\hline$\left(\mathrm{K}_{5}\right) 20+35$ & $10.36 \mathrm{abc}$ & $10.32 \mathrm{ab}$ & $12.42 \mathrm{ab}$ & $12.33 \mathrm{ab}$ & $0.455 \mathrm{a}$ & $0.456 \mathrm{a}$ \\
\hline$\left(\mathrm{K}_{6}\right) 20+50$ & $10.45 \mathrm{ab}$ & $10.34 \mathrm{ab}$ & $12.48 \mathrm{ab}$ & $12.26 \mathrm{ab}$ & $0.456 \mathrm{a}$ & $0.458 \mathrm{a}$ \\
\hline$\left(\mathrm{K}_{7}\right) 35+50$ & $10.52 \mathrm{ab}$ & $10.42 \mathrm{a}$ & $12.17 \mathrm{abc}$ & $11.90 \mathrm{abc}$ & $0.464 \mathrm{a}$ & $0.467 \mathrm{a}$ \\
\hline$\left(\mathrm{K}_{8}\right) 20+35+50$ & $10.71 \mathrm{a}$ & $10.53 \mathrm{a}$ & $12.58 \mathrm{a}$ & $12.48 \mathrm{a}$ & $0.460 \mathrm{a}$ & $0.458 \mathrm{a}$ \\
\hline \multicolumn{1}{|c|}{$\mathrm{F}$ Test } & $*$ & $*$ & $*$ & $*$ & NS & NS \\
\hline
\end{tabular}

${ }^{*},{ }^{* *}$ and N.S. indicate $\mathrm{P}<0.05, \mathrm{P}<0.01$ and not significant, respectively. Means of each factor designated by the same latter are not significantly different at $5 \%$ level using Duncan's Multiple Range Test

Characters studied of grain quality (hulling, milling, and head rice percentages) after different storage periods (0, 3, 6 and 9 months) as affected by potassium foliar application were presented in Fig 1. Foliar application of potassium generally enhanced the milling recovery characteristics at all storage periods. Spraying potassium sulphate three times $\left(K_{8}\right)$ at different growth stages caused markable increases in all milling recovery characteristics regardless the storage periods. The positive effect of potassium application on those characteristics may be due to its role in the translocation of assimilates from vegetative parts to grains during reproductive stage (White and Karley, 2010 and Timsina et al., 2013). Regarding the storage periods, milling recovery characteristics tended to increase at 3 months then a slight reduction was observed for all potassium treatments except the control. At the control treatment the reduction in milling recovery characteristics at 6 and 9 months was sharply compared with those at 0 and 3 months. These results are confirmed with the findings of Mirtaleb et al., (2021). 


\section{A.S. Gharieb}

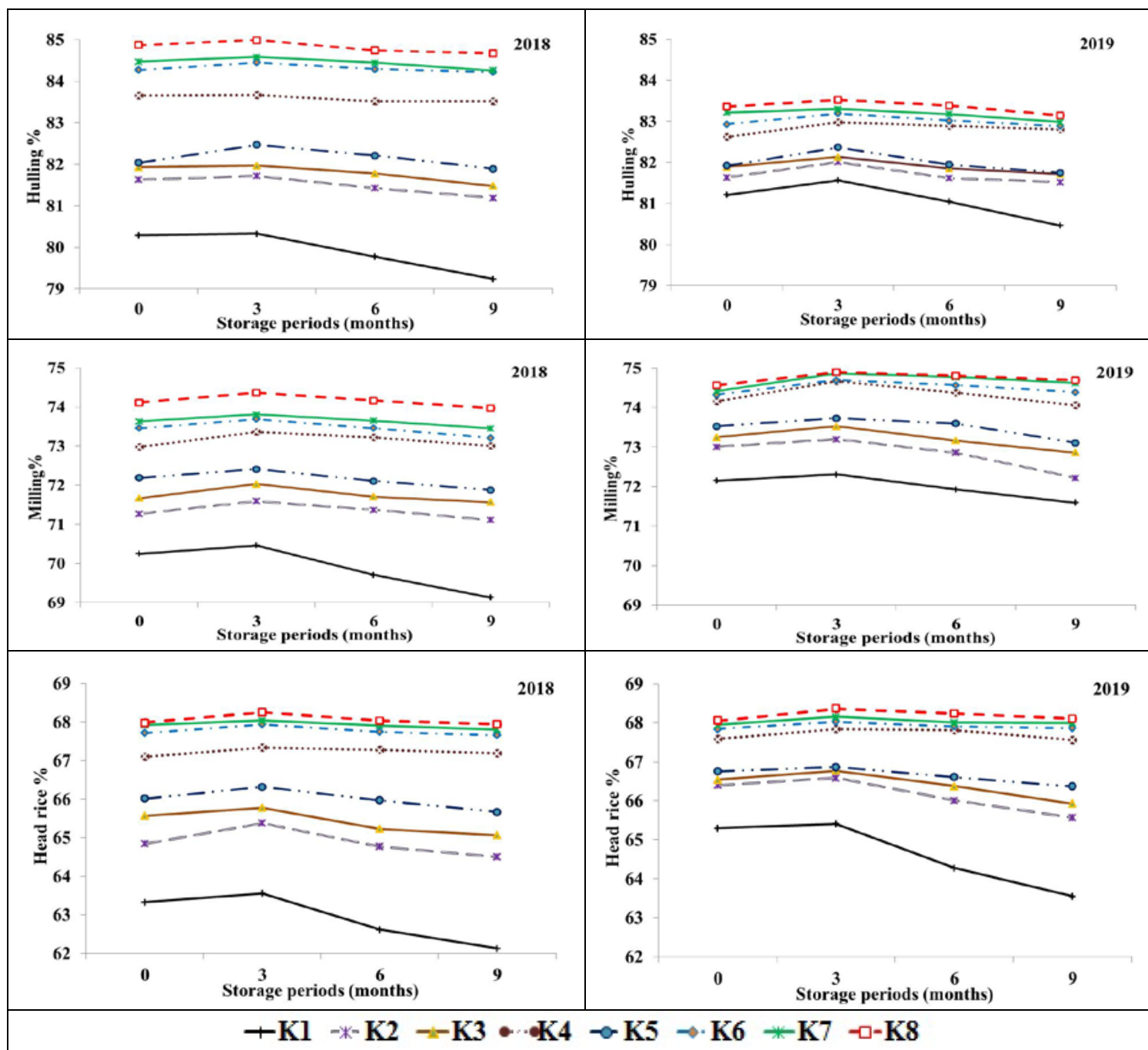

$\mathrm{K}_{1}$ : Control, $\mathrm{K}_{2}$ : spray at $20 \mathrm{DAT}, \mathrm{K}_{3}$ : spray at 35 DAT, $\mathrm{K}_{4}$ : spray at $50 \mathrm{DAT}, \mathrm{K}_{5}$ : Spray at 20 and 35 DAT, $K_{6}$ : spray at 20 and 50 DAT, $K_{7}$ : spray at 35 and 50 DAT and $K_{8}:$ spray at 20, 35 and 50 DAT.

Fig 1: Hulling, milling and head rice percentage of grains as affected by foliar spraying with potassium at different storage periods in the 2018 and 2018.

Nitrogen and potassium contents in the milled grain of rice were significantly affected by foliar application of potassium. Application of potassium significantly increased nitrogen and potassium contents in rice grain. The effect of potassium application on nitrogen and potassium contents in grain was attributed mainly to that nitrogen and potassium uptake and transport to aerial plant parts involve potassium cycle therefore, nitrogen and potassium uptake and transport in plants must be dependent on adequate potassium concentration in plant. Nitrogen and potassium content in rice grain increased significantly at 3 months compared with 0 (milling just after harvesting). The translocation of minerals during the storage from pericarp seed coat, aleurone layer and embryo to the endosperm is well known. A notable reduction was observed gradually in nitrogen and potassium content in rice grain at late storage periods. This reduction might be associated with the endosperm degradation during the long storage periods (White and Karley, 2010 and Timsina et al., 2013;). 


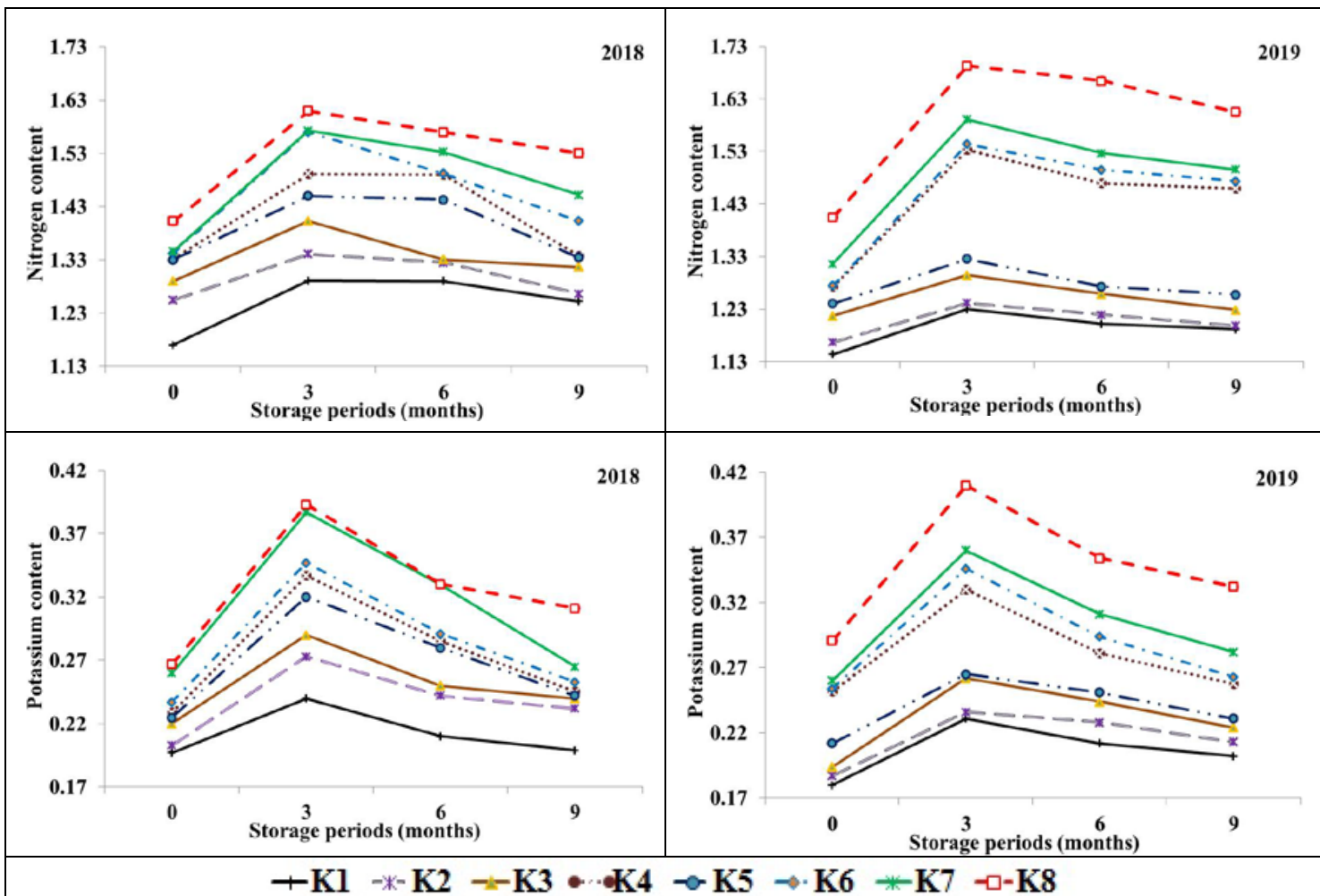

$\mathrm{K}_{1}$ : Control, $\mathrm{K}_{2}$ : spray at $20 \mathrm{DAT}, \mathrm{K}_{3}$ : spray at $35 \mathrm{DAT}, \mathrm{K}_{4}$ : spray at $50 \mathrm{DAT}, \mathrm{K}_{5}$ : Spray at 20 and 35 DAT, $K_{6}$ : spray at 20 and 50 DAT, $K_{7}$ : spray at 35 and 50 DAT and $K_{8}$ : spray at 20,35 and 50 DAT.

Fig. 2: Nitrogen and potassium content of milled grains as affected by foliar spraying with potassium at different storage periods in the two seasons.

\section{CONCLUSION}

The results showed that all studied traits were affected significantly by foliar application potassium at different growth stages. Based on the result it may be recommended that Foliar application of potassium three times at $(20,35$ and 50 DAT) exceeded other treatments in terms of yield quantity and quality.

\section{REFERENCES}

Adair, C. (1952). The McGill miller method for determining the milling quality of small samples of rice. Rice $J$ 55: 2123.

Ahmad, U., L. Alfaro, M. Yeboah-Awudzi, E. Kyereh, B. Dzandu, F. Bonilla, A. Chouljenko, and S. Sathivel (2017). Influence of milling intensity and storage temperature on the quality of
Catahoula rice (Oryza sativa L.). LWT 75: 386-392.

Ali, A., M. Salim, M. Zia, I. Mahmood and A. Shahzad (2005). Performance of rice as affected by foliar application of different $\mathrm{K}$ fertilizer sources. Pakistan Journal of Agricultural Sciences 42: 38-41.

Boonchuay, P., I. Cakmak, B. Rerkasem and C. Prom-U-Thai (2013). Effect of different foliar zinc application at different growth stages on seed zinc concentration and its impact on seedling vigor in rice. Soil Science and Plant Nutrition 59: 180-188.

Duncan, D. B. (1955). Multiple range and multiple $\mathrm{F}$ tests. Biometrics 11, 1-42.

El-Dalil, M. A. (2017). Effect of parboiling and storage periods on grain quality 
characters of $\mathbf{G 1 7 9}$ rice cultivar. Clearing 4, 4.59.

Fageria, N., N. Slaton and V. Baligar (2003). Nutrient management for improving lowland rice productivity and sustainability. Advances in agronomy 80, 63-152.

FAO (2016). Food and Agriculture Organization of the United Nations. Rice Market Monitor, 7.

Gomez, K. A. and A. A. Gomez (1984). "Statistical procedures for agricultural research," John Wiley \& Sons.

Islam, A., J. Chandrabiswas, A. Sirajulkarim, M. Salmapervin and M. Saleque (2017). Effects of potassium fertilization on growth and yield of wetland rice in grey terrace soils of Bangladesh. Research on Crop Ecophysiology 10: 64-82.

Jackson, M. (1967). Soil Chemical Analysis Prentice Hall of Indica, New Delhi. Jat.

Jagathjothi, N., P. Muthukrishnan and M. M. Amanullah (2012). Influence of foliar nutrition on growth and yield of transplanted rice. Madras Agricultural Journal 99: 275-278.

Jian-chang, $X . \quad$ (2004). Potassium nutrition of the rice-wheat cropping system. Advances in Agronomy 81: 203.

Jones, J. B. (2001). "Laboratory guide for conducting soil tests and plant analysis," CRC press.

Khan, A. W., R. A. Mann, M. Saleem and A. Majeed (2012). Comparative rice yield and economic advantage of foliar KNO3 over soil applied K2SO4. Pak. J. Agri. Sci 49, 481-484.

Kundu, A., P. Raha, A. N. Dubey, M. Rani, A. Paul and R. Patel (2020). Differential responses of rice (Oryza sativa L.) to foliar fertilization of organic potassium salts. Journal of Plant Nutrition, 1-19.
Li-Jun, L., E.H. Chang, F. Miao-Miao, W. Zhi-Qin and Y. Jian-Chang (2011). Effects of potassium and calcium on root exudates and grain quality during grain filling. Acta Agronomica Sinica 37, 661-669.

Mardanluo, S., M. K. Souri and M. Ahmadi (2018). Plant growth and fruit quality of two pepper cultivars under different potassium levels of nutrient solutions. Journal of plant nutrition 41: 16041614.

Marschner, H. (2011). "Marschner's mineral nutrition of higher plants," Academic press.

Mirtaleb, S. H., Y. Niknejad and H. Fallah (2021). Foliar spray of amino acids and potassic fertilizer improves the nutritional quality of rice. Journal of Plant Nutrition, 1-14.

Naeem, E. (2016). Response of Egyptian hybrid rice variety to soil and foliar application of potassium sulfate fertilizer. Journal of Plant Production 7: 257-262.

Nguyen, T. Q. and K. Goto (2009). Effects of heat shock treatment on rice quality during dtorage (Part 2): Nutritional and Pasting Properties Changes. Engineering in Agriculture, Environment and Food 2, 89-95.

Okasha, A. M., M. Abbelhameed and O. M. Elshayb (2019). Improving rice grain quality and yield of Giza 179 rice cultivar using some chemical foliar spray at late growth stages under salt stress. Journal of Plant Production 10, 769-775.

Park, C.E., Y.S. Kim, K.J. Park and B.K. Kim (2012). Changes in physicochemical characteristics of rice during storage at different temperatures. Journal of stored products research 48: 25-29.

Peterburgski, A. (1968). Hand Book of Agronomic Chemistry. Kolos 
Puplishing House, Moscow,(in Russian, pp. 29-86.

Rekani, S. I. (2020). Effect of foliar application of potassium on growth and yield of submergence rice grown in calcareous Soil. International Journal of Agriculture Innovations and Research. 9: 97-101.

Srivastava, P., P. C. Srivastava, U. Singh and M. Shrivastava (2009). Effect of integrated and balanced nutrient application on soil fertility, yield and quality of Basmati rice. Archives of Agronomy and Soil Science 55: 265284.

Timsina, J., Kumar Singh, V. and K. Majumdar (2013). Potassium management in rice-maize systems in South Asia. Journal of Plant Nutrition and Soil Science 176: 317-330.
Wang, H., L. Wu and Q. Tao (2004). Nitrate accumulation and variation of nutrient quality in pakchoi after application of several amino acids in summer and autumn. J. Agro-Environ. Sci 23: 224-227.

Wang, M., Q. Zheng, Q. Shen and S. Guo (2013). The critical role of potassium in plant stress response. International journal of molecular sciences 14: 7370-7390.

White, P. J. and A. J. Karley (2010). Potassium. In "Cell biology of metals and nutrients", pp. 199-224. Springer.

Zhou, Z., K. Robards, S. Helliwell and C. Blanchard (2002). Ageing of stored rice: changes in chemical and physical attributes. Journal of Cereal Science 35: 65-78. 


\section{A.S. Gharieb}

تأثير رش البوتاسيوم في مراحل النمو المختلفة علي انتاجية الارز وجودة الحبوب عند مراحل تحزين مختلفة

$$
\text { عبدالفتاح صبحي غربب المديل }
$$

مركز البحوث والتدريب في الارز-معهد بحوث المحاصيل الحقلية- مركز البحوث الزراعية- كفرالثيخ- مصر

$$
\text { الملخص العربى }
$$

أجريت تجربتان حقليتان بالمزرعة البحثية لمركز البحوث الزراعية-محطة بحوث سخا -كفرالثيخ - مصر في موسمي

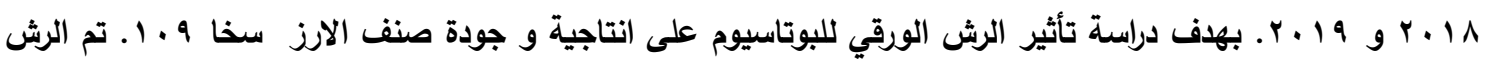

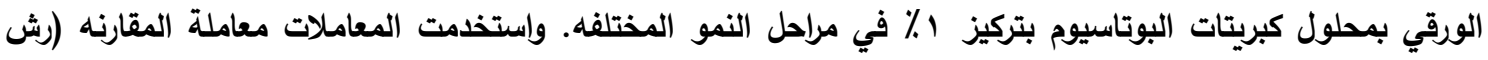

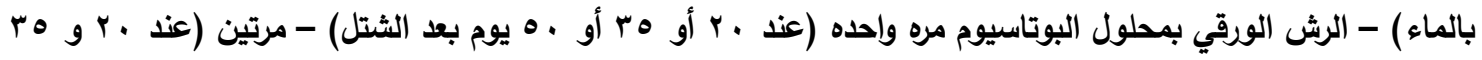

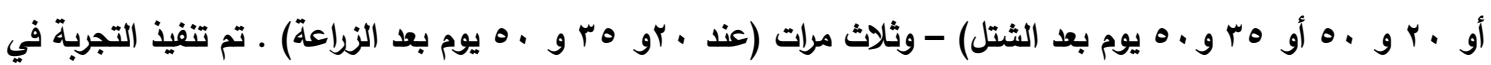

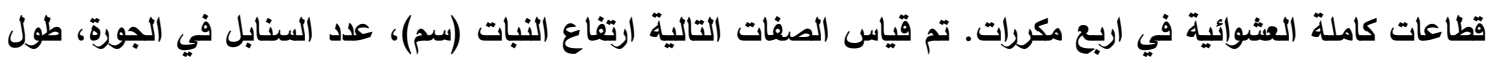

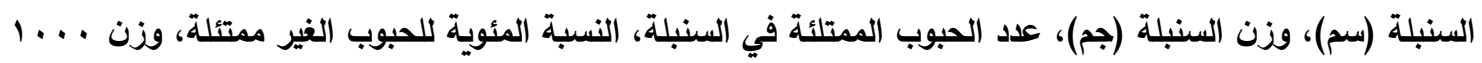

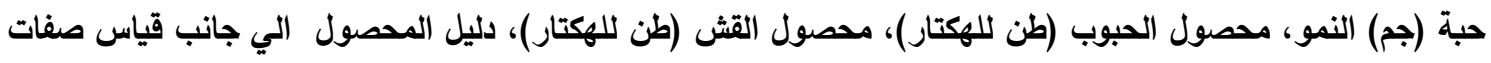

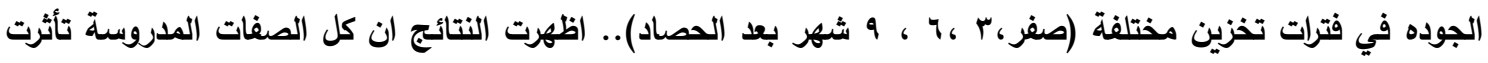

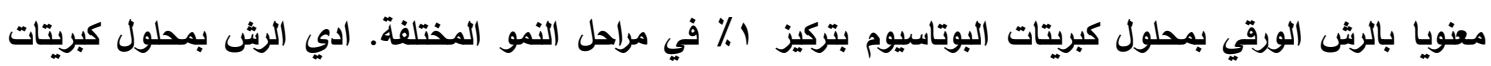

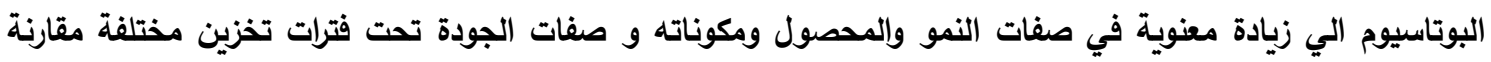

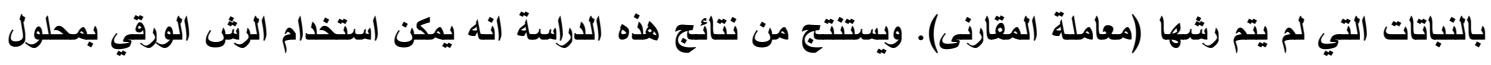

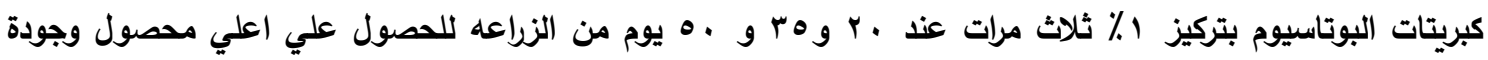
حبوب للصنف سخا 9 ـ 1.

أسماء السادة المحكمين

قسم بحوث الأرز - مركز البحوث الزراعية أ.د. تامر فاروق متولـى الــ

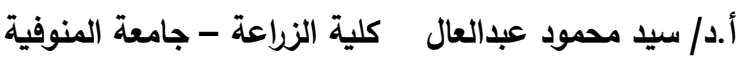

